\title{
KARAKTERISTIK NANOEMULSI EKSTRAK KULIT BUAH MANGGIS (Garcinia mangostana L.)
}
Lina, N. W. M. ${ }^{1}$, Maharani, T. ${ }^{1}$, Sutharini, M. R. ${ }^{1}$, Wijayanti, N. P. A. D. ${ }^{1}$, Astuti, K. W. ${ }^{1}$

${ }^{1}$ Jurusan Farmasi Fakultas Matematika Dan Ilmu Pengetahuan Alam Universitas Udayana

Korespondensi: Ni Wayan Milka Lina

Jurusan Farmasi Fakultas Matematika dan Ilmu Pengetahuan Alam Universitas Udayana Jalan Kampus Unud-Jimbaran, Jimbaran-Bali, Indonesia 80364 Telp/Fax: 703837

Email: milkalina73@yahoo.com

\begin{abstract}
ABSTRAK
Penggunaan ekstrak kulit buah manggis secara langsung dapat menimbulkan ketidaknyamanan dan memiliki ukuran partikel besar sehingga penetrasi dan absorpsinya pada kulit kurang baik, untuk itu dibuat dalam bentuk nanoemulsi dengan Self Nanoemulsifying Drug Delivery System untuk aplikasi topikal. Penggunaan nanoemulsi pada kulit dapat meningkatkan penetrasi dan absorpsi bahan aktif melalui kulit tanpa perlu menambahkan eksipien penetrasi lain dan memiliki luas permukaan yang besar sehingga lebih efektif sebagai sistem pembawa. Penelitian ini bertujuan untuk mengetahui karakteristik ektrak etil asetat kulit buah manggis yang dikorporasikan kedalam bentuk nanoemulsi dan untuk mengetahui sifat fisika sediaan nanoemulsi.

Nanoemulsi dibuat dengan komposisi Virgin Coconut Oil sebagai fase minyak, Etanol 96\% sebagai kosurfaktan, Cremofor RH 40 sebagai surfaktan, dan aqua deion sebagai fase air dengan perbandingan 1:7:2:5, kemudian campuran tersebut distirrer dan disonikasi lalu dilakukan pengujian stabilits fisik dan diukur nilai persen transmitan pada panjang gelombang $650 \mathrm{~nm}$ dengan spektrofotometri UV-Vis.

Didapatkan hasil analisis keseluruh formula nanoemulsi, semakin banyak jumlah ekstrak kulit buah manggis yang diinkorporasikan ke dalam fase minyak, maka warna nanoemulsi yang terbentuk semakin pekat dan nilai persen trasmitan yang dihasilkan juga akan semakin kecil.
\end{abstract}

Kata Kunci : kulit buah manggis (Garcinia mangostana L.), nanoemulsi, SNEDDS, VCO.

\section{PENDAHULUAN}

Manggis (Garcinia mangostana

L.) merupakan tanaman tropis yang banyak ditemukan di Asia Tenggara, termasuk Indonesia. Xhantone merupakan salah satu senyawa dalam kulit buah manggis yang telah diketahui memiliki aktivitas sebagai antifungal, antimikroba, antioksidan dan sitotoksik (Suksamrarn et al., 2003). Berdasarkan penelitian Khumsupan dan Gritsanapan (2013), menyatakan bahwa alfa mangostin yang merupakan derivat xhantone memiliki aktivitas farmakologi sebagai antidoksidan, antiinflamasi dan antibakteri terhadap S. aureus, $P$. acne, dan M. tubercolusis. 
Berdasarkan penelitian fitri (2016), dilakukan optimasi terhadap pelarut ekstraksi kulit buah manggis dan diperoleh hasil bahwa pelarut etil asetat menghasilkan kadar alfa mangostin yang tertinggi dibandingkan dengan pelarut etanol dan methanol. Sehingga, dalam penelitian ini digunakan pelarut etil asetat dalam pembuatan nanoemulsi dengan menggunakan ekstraksi kulit buah manggis. Nanoemulsi adalah emulsi yang transparan dan stabil secara termodinamika yang memiliki rentang ukuran partikel 5-200 nm (Mishra et al., 2014).

Nanoemulsi dibuat dalam sistem pengantaran obat yang disebut dengan Self-Nanoemulsifying Drug Delivery System (SNEDDS). SNEDDS adalah campuran dari minyak, surfaktan, kosurfaktan dan zat aktif yang ketika bercampur dengan air akan membentuk nanoemulsi tipe minyak/air (M/A) (Sokolov, 2014). Karakteristik nanoemulsi sangat erat kaitannya dengan stabilitas fisik dan kejernihan karena akan berpengaruh penting terhadap ukuran partikel yang dihasilkan. Ukuran globul yang besar dapat menyebabkan terjadinya sedimentasi dan creaming, sehingga perlu dilakukan karakteristik terhadap stabilitas fisik dan kejernihan dari nanoemulsi ekstrak etil asetat kulit buah manggis yang dihasilkan.

\section{BAHAN DAN METODE}

2.1 Bahan

Bahan yang digunakan dalam penelitian ini adalah kulit buah manggis (Garcinia mangostana L.) yang diperoleh dari daerah LuwusTabanan Bali, bahan kimia dengan derajat teknis Etil Asetat, Aquades, Virgin Coconut Oil (Asian Chemical), Cremofor RH 40 (Asian Chemical), Etanol 96\% (Asian Chemical), dan Aqua Deion (Asian Chemical).

2.2 Metode Penelitian

2.2.1 Penyiapan Sampel Buah Manggis dan Determinasi Tanaman

Buah manggis yang dipilih adalah buah yang matang dan berwarna ungu kehitaman yang diperoleh dari Desa Luwus, Kecamatan Baturiti, Kabupaten Tabanan, Bali. Determinasi tumbuhan dilakukan di UPT Balai Konservasi Tumbuhan Kebun Eka Karya Bedugul, Tabanan, Bali. Kulit buah manggis yang telah dikumpulkan dan dicuci, kemudian dipotong kecil-kecil dan ditimbang.

2.2.2 Preparasi Sampel Kulit Buah Manggis

Kulit buah manggis yang telah dipotong kecil-kecil, diserbuk. Kemudian dilakukan difating dan disaring. Hasil defating dimaserasi menggunakan etil asetat. Maserat diremaserasi kembali sebanyak 1 kali. Filtrat yang diperoleh kemudian dipekatkan dengan rotary evaporator sehingga diperoleh ekstrak kental. Ekstrak dikeringkan menggunakan metode freeze drying hingga diperoleh serbuk (Fitri, 2016).

2.2.3 Pembuatan Nanoemulsi Ekstrak Etil Asetat Kulit Buah Manggis

Variasi penambahan jumlah ekstrak etil asetat kulit buah manggis $(10,25,50,100,150,200,250,350$, 500 , dan 750mg) disuspensikan dalam Virgin Coconut Oil, dengan pengaduk magnetik, kemudian ditambahkan dengan etanol dan 
terakhir ditambahkan Chremofor RH40 dan diaduk dengan pengaduk magnetik (200 rpm). Setelah itu, campuran ditempatkan dalam sonikator tipe bath selama 1 jam. Campuran tersebut kemudian ditambahkan dengan aqua deion, dan diaduk secara manual sehingga terbentuk nanoemulsi, lalu dilakukan pengukuran stabilitas fisik dan persen transmitan (Budiputra et al., 2014).

2.2.4 Uji Evaluasi Nanoemulsi Ekstrak Etil Asetat Kulit Buah Manggis

a. Pengujian Persen Transmitan (\%)

Sampel sebanyak $1 \mathrm{~mL}$ dilarutkan dalam labu takar $100 \mathrm{~mL}$ dengan menggunakan aqua deion. Larutan diukur persen transmitannya pada panjang gelombang $650 \mathrm{~nm}$ menggunakan spektrofotometri UVVis. Aqua deion digunakan sebagai blangko saat pengujian (Pratiwi et al., 2016). Formulasi yang memiliki persentase transmitan 90\%-100\% menunjukkan bahwa formulasi tersebut memiliki penampakan visual yang jernih dan transparan (Costa et al., 2012).

c. Uji Stabilitas Fisik

Stabilitas fisik nanoemulsi dilakukan dengan uji sentrifugasi pada kecepatan 12000 rpm selama 15 menit kemudian dilakukan pengamatan. Nanoemulsi yang stabil dapat diamati dengan tidak terjadi pemisahan pada kedua fase (Budiputra et al., 2014).

3. HASIL

Tabel 1. Hasil Pengujian Nanoemulasi Ekstrak Etil Asetat Kulit Buah Manggis

\begin{tabular}{cccc}
\hline Formula & $\begin{array}{c}\text { Konsetrasi Ekstrak } \\
(\mathrm{mg})\end{array}$ & $\begin{array}{c}\text { Uji Persen Transmitan } \\
(\%)\end{array}$ & Uji Stabilitas Fisik \\
\hline F1 & 10 & 88,9 & Jernih \\
F2 & 25 & 85,8 & Jernih \\
F3 & 50 & 68,1 & Jernih \\
F4 & 100 & 55,9 & Jernih \\
F5 & 150 & 38,2 & Jernih \\
F6 & 200 & 31,4 & Jernih \\
F7 & 250 & 31,4 & Ada Pelet \\
F8 & 350 & 30,2 & Ada Pelet \\
F9 & 500 & 28,1 & Ada Pelet \\
F10 & 750 & 16,3 & Ada Pelet \\
\hline
\end{tabular}



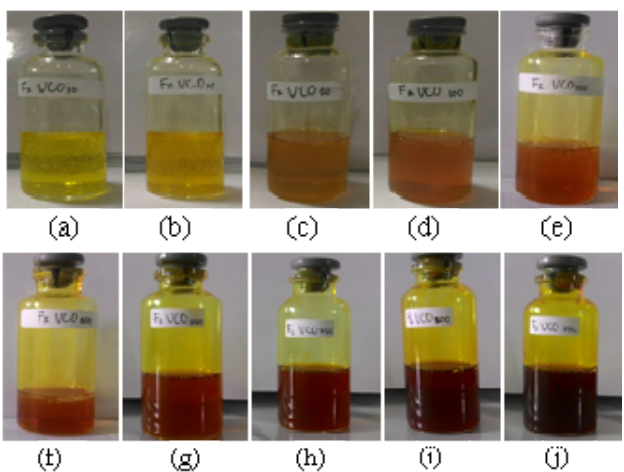

Gambar 1. Hasil Pembuatan Nanoemulsi Ekstrak Etil Asetat Kulit Buah Manggis dengan Konsentrasi a (10 mg) , b (25 mg), c (50 mg), d (100) mg, e (150 mg), $\mathrm{f}(200 \mathrm{mg}), \mathrm{g}(250 \mathrm{mg}), \mathrm{h}(350 \mathrm{mg}), \mathrm{i}(500 \mathrm{mg})$, dan j (750 mg)
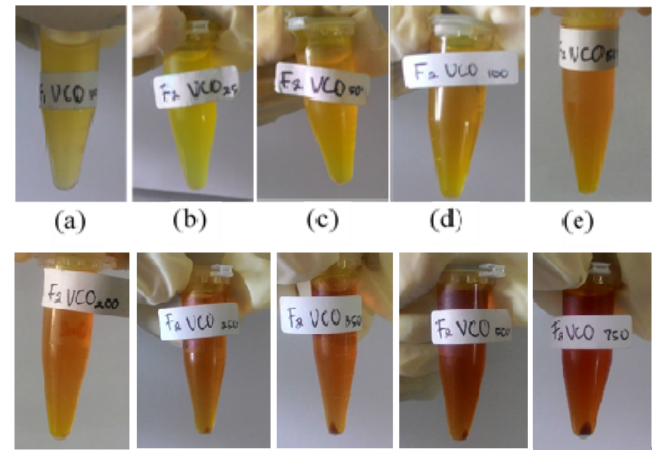

(f)

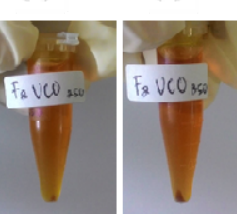

$(\mathrm{g})$

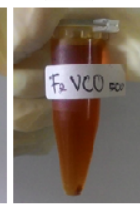

(i) (e)

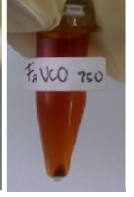

(j)

Gambar 2. Uji Stabilitas Fisik Nanoemulsi Ekstrak Kulit Buah Manggis dengan Konsentrasi a (10 mg) , b (25 mg), c (50 mg), d (100) mg, e (150 mg), f (200 mg), $\mathrm{g}(250 \mathrm{mg}), \mathrm{h}(350 \mathrm{mg}), \mathrm{i}(500 \mathrm{mg})$, dan j (750 mg)

\section{PEMBAHASAN}

Berdasarkan Gambar 1. karakterisasi secara visual nanoemulsi terlihat jernih dan transparan. Namun, semakin banyak jumlah ekstrak kulit buah manggis yang diinkorporasikan ke dalam fase minyak, maka nanoemulsi yang terbentuk semakin pekat. Hal ini berarti terdapat batasan jumlah ekstrak kulit manggis yang dapat diinkorporasikan ke dalam sistem nanoemulsi. Kapasitas pengisian ekstrak kulit buah manggis dalam nanoemulsi kemungkinan bergantung pada kelarutannya di dalam sistem yang digunakan (campuran minyak, surfaktan dan kosurfaktan).

Berdasarkan Tabel 1. Hasil pengujian stabilitas fisik dan persen transmitan yang terbentuk menunjukkan semakin banyak ekstrak kulit buah manggis yang ditambahkan semakin pekat warna yang dihasilkan dan semakin kecil nilai persen tranmitan yang diperoleh. Menurut Costa et al (2012), nanoemulsi yang baik memiliki penampakan visual yang jelas dengan transmitan tinggi. Formulasi yang memiliki persentase transmitan tertinggi $\quad 90 \%-100 \%$ menunjukkan penampakan visual formulasi jernih dan transparan. Dari 
data yang diperoleh pada Tabel 1 . menunjukkan bahwa ke-10 formula belum ada yang memenuhi syarat uji persen transmitan yang memasuki rentang, maka untuk itu perlu dilakukan penurunan konsentrasi ekstrak etil asetat kulit buah manggis $<10 \mathrm{mg}$, agar dapat memenuhi syarat uji persen transmitan.

\section{KESIMPULAN}

Semakin banyak jumlah ekstrak kulit buah manggis yang diinkorporasikan ke dalam fase minyak, maka warna nanoemulsi yang terbentuk semakin pekat dan nilai persen trasmitan yang dihasilkan juga akan semakin kecil.

\section{UCAPAN TERIMA KASIH}

Direktorat Jendral Pembelajaran dan

Kemahasiswaan

Kemenristekdikti atas bantuan dana yang telah diberikan dan Gede Pasek selaku Laboran di Laboratorium Teknologi Non Steril Jurusan Farmasi, Fakultas MIPA, Universitas Udayana atas fasilitas yang telah diberikan selama proses penelitian ini.

\section{DAFTAR PUSTAKA}

Budiputra, D.K., H. Rachmawati, and R. Mauludin. 2014. Curcumin Nanoemulsion For Transdermal Application: Formulation And Evaluation. Drug Development And Industrial Pharmacy. 1-7.

Costa, J. A., Lucas, E. F., Queiros, Y. G. C., Mansur, C. R. E. 2012. Evaluation Of Nanoemulsions In The Cleaning Of Polymeric Resins. Colloids Surf Physicochem. Eng. Asp. 415. Pp. 112-118.
Fitri, N.P.E. 2016. Optimasi Pelarut dan Waktu Maserasi Ekstrak Kulit Buah Manggis (Garcinia mangostana L.). Skripsi. Jimbaran: Universitas Udayana.

Khumsupan, P., dan Gritsanapan, W. 2013. Selected Thai Medicinal Plant for The Treatment of Acne: Garcinia mangostana Linn. in M. L. Elsaie (Ed.), Acne: Etiology, Treatment Options and Social Effects (pp. 51-60). New York: Nova Science Publishers, Inc.

Mishra R.K., G.C. Soni, R.P. Mishra. 2014. Review Article: On Nanoemulsion. World Journal of Pharmacy and Pharmaceutical Science. Vol. 3 (9): 258-274.

Pratiwi, L., A. Fudholi, R. Martien, S. Pramono. 2016. Design And Optimization Of SelfNanoemulsifying Drug Delivery Systems (SNEDDS) Of Ethyl Acetate Fraction From Mangosteen Peel (Garcinia Mangostana, L.). International Journal of PharmTech Research. Vol. 9 (6). pp 380387.

Sokolov, Y. V. 2014. Nanoemulsion Formulation By Low-Energy Methods: A Review. News of Pharmacy. Vol. 3 (79). Pp. 1618.

Suksamrarn S, Suwannapoch N, Phakhodee W, Thanuhiranlert J, Ratananukul P, Chimnoi N, Suksamrarn A. 2003. Antimycobacterial activity of Prenylated Xanthones from The Fruits of Garcinia mangostana. Chem Pharm Bull (Tokyo). Vol. 51(7):857-859. 